\title{
Hjemmetjenesten driver omfattende
}

\section{laboratorievirksomhet}

De fleste hjemmetjenestene i Nordland, Sogn og Fjordane og Østfold utfører mange ulike laboratorietjenester, viser en kartlegging.

\section{Forfattere}

\section{Siri Fauli}

Prosjektleder for hjemmetjenesteprosjektet og helseøkonom

Noklus, Haraldsplass Diakonale Sykehus

\section{Sverre Grepperud}

Professor i helseøkonomi

Institutt for helse og samfunn, Universitetet i Oslo

\section{Sverre Sandberg}

Leder og professor

Noklus, Haraldsplass Diakonale Sykehus, Nasjonalt kompetansesenter for porfyrisykdommer (NAPOS),

Haukeland universitetssjukehus og Institutt for global helse og samfunnsmedisin, Universitetet i Bergen

\section{Nøkkelord}

Blodprøve Hjemmesykepleie Kvalitet Laboratorievirksomhet

Sykepleien Forskning 2018 13(65107)(e-65107)

DOI: 10.4220/Sykepleienf.2018.65107

\section{SAMMENDRAG}

Bakgrunn: Det er lite kunnskap i helsetjenesten om hvilke laboratorietjenester som ytes for de om lag 145000 norske brukere av hjemmetjenesten som mottar hjemmesykepleie.

Hensikt: Denne studien har kartlagt laboratorievirksomheten i hjemmetjenesten i Nordland, Sogn og Fjordane og Østfold.

Metode: Vi hentet inn data om laboratorievirksomhet i hjemmetjenesten ved å sende ut en nettbasert undersøkelse til 165 hjemmetjenesteenheter og 220 fastlegekontorer i de tre fylkene i 2014. Svarprosenten var på henholdsvis 89 og 84 . 
Resultat: Nittifem prosent av enhetene utfører laboratoriearbeid. Av disse analyserer 99 prosent kapillære prøver. Nittiseks prosent utfører urinstrimmeltest, mens 89 prosent tar venøse prøver. Av dem som tar kapillære prøver, analyserer 99 prosent glukose, 56 prosent C-reaktivt protein (CRP), 46 prosent hemoglobin, mens 32 prosent analyserer protrombintid internasjonal normalisert ratio (INR). Hovedsakelig er det fastlegene som rekvirerer venøse prøver og kapillær INR, glukose og hemoglobin, mens hjemmetjenesten ofte selv rekvirerer urinstrimmeltest og CRP. Fastlegekontorene tror de selv rekvirerer en høyere andel av CRP enn de faktisk gjør.

Konklusjon: Hjemmetjenesteenhetene har en omfattende laboratorievirksomhet med et analyserepertoar ganske likt det som finnes på sykehjemmene. Gitt det omfattende tilbudet av laboratorietjenester som utføres av hjemmetjenesten og det høye antallet ansatte involvert i slike aktiviteter, er det viktig med kvalitetssikringssystemer kombinert med tilstrekkelig faglig kompetanse.

Hjemmetjenesten er et lovpålagt kommunalt tilbud som skal sikre innbyggerne nødvendige helse- og omsorgstjenester (1). Brukerne av hjemmetjenester inngår som en del av fastlegenes listeansvar og skal prioriteres på lik linje med andre listepasienter (2). Det var cirka 145000 brukere av hjemmetjenesten i 2015 som mottok hjemmesykepleie (3).

De ansatte i hjemmetjenesten utfører også visse laboratorietjenester, men det er lite systematisk kunnskap om omfanget av og innholdet i denne typen tjenester. For eksempel kjenner vi ikke til hvilke prøver som analyseres pasientnært (PNA) hjemme hos brukeren. Samtidig er det grunn til å tro at samhandlingsreformen (4), som ønsker at flere skal behandles i hjemmene sine, vil føre til økt laboratorievirksomhet i regi av hjemmetjenesten.

Når det gjelder laboratorievirksomheten på legekontorene og $\mathrm{i}$ sykehjemmene, finnes det relativt god kunnskap om hvilke analyser som utføres. For eksempel viser data fra 2014 at 95 prosent av sykehjemmene utfører analyser av C-reaktivt protein (CRP) og urinstrimmel, 98 prosent analyserer glukose, 79 prosent analyserer hemoglobin, mens 40 prosent analyserer protrombintid internasjonal normalisert ratio (INR) (5).

\section{Laboratorietjenester utført av hjemmetjenesten}

Alternativene til at hjemmetjenesten selv utfører

laboratorietjenester vil være 1) at helsepersonell (ambulerende laboratoriepersonell fra sykehus eller private laboratorier, eller ansatte fra fastlegekontor) reiser ut til brukerne, eller 2) at brukerne selv transporteres til nærmeste prøvetakingssted (6). 
Brukerens reiseavstand til nærmeste prøvetakingssted og avstanden fra hjemmetjenesten til laboratorier på sykehjem eller legekontor kan ha betydning for hvordan hjemmetjenesteenhetene er organisert, og for hvilke tjenester som utføres. For eksempel kan hjemmetjenester som er samlokalisert med sykehjem, lettere samarbeide om laboratorievirksomheten.

\section{三 «vis hjemmetjenesten selv tilbyr laboratorietjenester, er mulige fordeler at brukerne unngår strevsomme reiser og får raskere prøvesvar.»}

Hvis hjemmetjenesten selv tilbyr laboratorietjenester, er mulige fordeler at brukerne unngår strevsomme reiser og får raskere prøvesvar. Mulige ulemper er at kvaliteten på de laboratorietjenestene som ytes, ikke blir tilfredsstillende på grunn av manglende kompetanse.

Laboratorietjenester, som andre helsetjenester, har behandlingsmessige konsekvenser og krever ressurser. Det er derfor viktig at slike tjenester utføres på riktig måte og på riktig nivå. En kartlegging av omfang og struktur på laboratorievirksomheten i hjemmetjenesten blir dermed viktig for å kunne vurdere en fremtidig hensiktsmessig organisering og kvalitetssikring av slike tjenester.

\section{Kartlegging av laboratorievirksomheten}

I denne artikkelen presenterer vi resultatene fra en kartlegging av laboratorievirksomheten i tre fylker. Kartleggingen var en del av et pilotprosjekt i 2014-2015 utført i regi av Norsk kvalitetsforbedring av laboratorieundersøkelser (Noklus). Kartleggingen inngår i Omsorgsplan 2015 (7) og skulle utgjøre en del av grunnlaget for fremtidige anbefalinger for hvordan laboratorievirksomheten i hjemmetjenesten skal organiseres (8).

Noklus er en landsdekkende ideell organisasjon som arbeider for at laboratorieanalyser blir rekvirert, utført og tolket riktig i samsvar med pasientens behov for utredning, behandling og oppfølging. Nesten alle legekontorene og sykehjemmene i landet er tilknyttet Noklus. Vi kjenner ikke til andre studier, verken nasjonale eller internasjonale, som har kartlagt laboratorievirksomheten i hjemmetjenesten. 
Imidlertid finnes det enkelte studier som undersøker

kompetansen blant de ansatte i hjemmetjenesten. I en studie av 1016 ansatte i sykehjem og hjemmetjenesten fant BingJonsson og medarbeidere (9) mangelfull kompetanse på visse områder, som sykepleietiltak, avanserte prosedyrer og dokumentasjon. De fant også at kompetansen var lavere i hjemmetjenesten enn i sykehjem.

I en studie av 209 ansatte i hjemmetjenesten i seks kommuner fant Bing-Jonsson og Tønnessen (10) at det var behov for kompetanseheving i forbindelse med å identifisere symptomer på urinveisinfeksjoner og anvende urinstrimler.

\section{Materiale og metode}

Vi utførte kartleggingen ved å sende ut en nettbasert spørreundersøkelse til samtlige hjemmetjenesteenheter i Nordland, Sogn og Fjordane og Østfold. Vi kontaktet totalt 165 enheter, der 79 var lokalisert i Nordland, 46 i Sogn og Fjordane og 40 i Østfold.

Hjemmetjenesteenhetene ble identifisert ut fra en oversikt produsert av Statistisk sentralbyrå. Deretter kvalitetssikret vi oversikten ved å kontakte utviklingssentrene for sykehjem og hjemmetjenester (11), og ved å innhente informasjon fra hjemmesidene til de enkelte kommunene.

Ulike begreper som soner, baser og avdelinger brukes om enhetene i de ulike kommunene. Derfor valgte vi i spørreundersøkelsen å definere en «hjemmetjenesteenhet» som det fysiske stedet der de ansatte er samlokalisert. Heretter anvender vi begrepet «enhet».

\section{Utarbeidelse av spørreskjemaet}

Vi utarbeidet spørreskjemaet i samråd med ansatte i Noklus og Noklus’ rådgivningsgruppe for hjemmetjenesten. En revidert versjon ble sendt på høring til to eller tre ulike enheter i hvert av de tre fylkene.

Våren 2014 sendte vi ut den endelige versjonen av spørreskjemaet med tre ukers svarfrist. Vi la ved et brev fra Helsedirektoratet som oppfordret enhetene til å svare på spørreskjemaet. En påminnelse på e-post ble sendt ut to uker etter utsendelse, og den siste uken purret vi per telefon dem som ikke hadde svart. 
Vi spurte om organisering av tjenesten, analyserepertoar og samarbeid med legekontorer og sykehjem. For å kunne vurdere hvor hensiktsmessig en gitt organisering var, spurte vi om 1) brukernes reisetid til nærmeste legekontor og 2) reisetid fra enhetene til nærmeste legekontor og sykehjem.

\section{Respons på spørreskjemaet}

146 av totalt 165 enheter (svarprosent 89) besvarte undersøkelsen, der 70 var fra Nordland, 40 fra Sogn og Fjordane og 36 fra Østfold. Vi registrerte svar fra enheter i samtlige kommuner i de tre fylkene.

Alternativene reisetid i spørreskjemaet var som følger: 0 (samlokalisert), 1-5, 6-15, 16-30, 30-60, 60-120 og mer enn 120. Få respondenter rapporterte mer enn 30 minutters reisetid, og tre av kategoriene er derfor slått sammen til kategorien «> 30 minutter».

Alle respondentene besvarte ikke alle spørsmålene, og derfor varierer responsratene noe. Vi benyttet kjikvadrattester til å teste forskjeller mellom fylkene. Til analysene brukte vi Microsoft Excel.

Samtidig med utsendelsen av spørreskjemaet til hjemmetjenesten sendte vi ut spørreskjema til alle fastlegekontorene i fylkene. Vi spurte om type og grad av samarbeid med hjemmetjenesten i forbindelse med laboratoriearbeid. På forhånd gjennomgikk fastleger i de tre fylkene spørreskjemaet. Deretter sendte vi det ut til 220 fastlegekontorer. Det ga en svarprosent på 83,6.

For å unngå for mange tabeller i resultatkapittelet valgte vi å rapportere enkelte av våre resultater kun i teksten. Vi valgte også ikke å presentere prosentandelene med desimaler på grunn av det relativt lave antallet observasjoner.

\section{Resultat}

Tabell 1, kjennetegn ved enhetene i fylkene, viser at Sogn og Fjordane har langt færre brukere som mottar hjemmesykepleie enn Nordland og Østfold. Hver enhet i Østfold har nesten tre ganger så mange brukere som enhetene i Sogn og Fjordane og nesten dobbelt så mange som enhetene Nordland.

\section{三 «Sogn og Fjordane har langt færre brukere som mottar hjemmesykepleie enn Nordland og Østfold.»}


Åttito prosent av enhetene oppga at de fleste av brukerne deres har mindre enn en halv times reisevei til nærmeste legekontor. Denne andelen er høyest for Østfold (100 prosent).

Tabell 1: Kjennetegn ved enhetene i fylkene

\begin{tabular}{|c|c|c|c|c|}
\hline & $\begin{array}{l}\text { Nordland } \\
N=70\end{array}$ & $\begin{array}{l}\text { Sogn og Fjordane } \\
N=40\end{array}$ & $\begin{array}{l}\emptyset \text { stfold } \\
N=36\end{array}$ & $\begin{array}{l}\text { Alle tre fylkene } \\
N=146\end{array}$ \\
\hline Antall innbyggere & 239611 & 108700 & 282000 & 630311 \\
\hline $\begin{array}{l}\text { Antall innbyggere } \\
\text { per kvadratkilometer (12) }\end{array}$ & 7 & 6 & 72 & 11 \\
\hline $\begin{array}{l}\text { Antall brukere som mottar } \\
\text { hjemmesykepleie* }\end{array}$ & 9014 & 3917 & 8793 & 21724 \\
\hline $\begin{array}{l}\text { Gjennomsnittlig antall brukere } \\
\text { per enhet* }\end{array}$ & 114 & 85 & 220 & 148 \\
\hline \multicolumn{5}{|l|}{$\begin{array}{l}\text { Enhetens størrelse basert } \\
\text { på antall ansatte i enhetene }\end{array}$} \\
\hline $1-20$ ansatte & 46 & 55 & 14 & 40 \\
\hline $21-40$ ansatte & 43 & 30 & 39 & 38 \\
\hline$>40$ ansatte & 10 & 15 & 47 & 21 \\
\hline \multicolumn{5}{|l|}{$\begin{array}{l}\text { Befolkningssgrunnlag } \\
\text { i enhetens ansvarsområde }\end{array}$} \\
\hline$<2000$ & 57 & 55 & 14 & 46 \\
\hline $2000-5000$ & 27 & 40 & 28 & 31 \\
\hline$>5000$ & 14 & 5 & 58 & 23 \\
\hline $\begin{array}{l}\text { Andel enheter der flertallet av } \\
\text { brukerne har mindre reisetid enn } \\
\text { en halvtime til nærmeste legekontor }\end{array}$ & 71 & 85 & 100 & 82 \\
\hline
\end{tabular}

Prosentvis fordeling. $\mathrm{N}=$ antall respondenter.

* Oppgitt av Statistisk sentralbyrå. Disse tallene er basert på følgende antall registrerte enheter i de tre fylkene: Nordland (79), Sogn og Fjordane (46) og Østfold (40).

Tabell 2 viser målt reisetid fra enhetene til nærmeste sykehjem og nærmeste legekontor i minutter. Totalt var 47 prosent av hjemmetjenesteenhetene samlokalisert med et sykehjem, mens 19 prosent var samlokalisert med et legekontor (tabell 2).

Andelen som var samlokalisert med sykehjem, var nokså jevnt fordelt mellom fylkene, mens Østfold hadde den laveste andelen som var samlokalisert med et legekontor. Tabell 2 viser dessuten at Østfold har den korteste reisetiden både til nærmeste sykehjem og nærmeste legekontor. 


\begin{tabular}{|c|c|c|c|c|c|c|c|c|}
\hline \multirow[b]{2}{*}{$\begin{array}{l}\text { Reisetid fra enhetene } \\
\text { til nærmeste }\end{array}$} & \multicolumn{2}{|c|}{$\begin{array}{l}\text { Nordland } \\
N=69\end{array}$} & \multicolumn{2}{|c|}{$\begin{array}{l}\text { Sogn og Fjor- } \\
\text { dane } N=40\end{array}$} & \multicolumn{2}{|c|}{$\begin{array}{l}\emptyset \text { stfold } \\
N=36\end{array}$} & \multicolumn{2}{|c|}{$\begin{array}{l}\text { Alle tre fylkene } \\
N=145\end{array}$} \\
\hline & $\begin{array}{l}\text { syke- } \\
\text { hjem }\end{array}$ & $\begin{array}{l}\text { lege- } \\
\text { kontor }\end{array}$ & $\begin{array}{l}\text { syke- } \\
\text { hjem }\end{array}$ & $\begin{array}{l}\text { lege- } \\
\text { kontor }\end{array}$ & $\begin{array}{l}\text { syke- } \\
\text { hjem }\end{array}$ & $\begin{array}{l}\text { lege- } \\
\text { kontor }\end{array}$ & $\begin{array}{l}\text { syke- } \\
\text { hjem }\end{array}$ & $\begin{array}{l}\text { lege- } \\
\text { kontor }\end{array}$ \\
\hline $\begin{array}{l}0 \text { minutter } \\
\text { (samlokalisering) }\end{array}$ & 46 & 20 & 50 & 23 & 47 & 14 & 47 & 19 \\
\hline 1-15 minutter & 35 & 68 & 15 & 58 & 44 & 83 & 32 & 70 \\
\hline 16-30 minutter & 9 & 7 & 18 & 10 & 3 & 3 & 9 & 7 \\
\hline$>30$ minutter & 9 & 4 & 18 & 10 & 6 & 0 & 10 & 5 \\
\hline Prosentvis fordeling. & & & & & & & & \\
\hline
\end{tabular}

Enhetene ble bedt om å svare ja eller nei på spørsmålet om hvorvidt de utfører prøvetaking og/eller analysering av blod eller urin. De av enhetene som besvarte dette spørsmålet positivt, betegner vi heretter som enheter som har laboratorievirksomhet. I de påfølgende tabellene er det kun denne gruppen vi rapporterer svarene fra.

I alt 139 av disse enhetene svarte ja (95 prosent) på spørsmålet - 96 prosent i Nordland, 98 prosent i Sogn og Fjordane og 92 prosent i Østfold. Enhetene ble også bedt om å besvare hvorvidt de foretok venøs prøvetaking eller ei. Prosentandelen som utførte venøs prøvetaking, var høy for Nordland (97 prosent) og Sogn og Fjordane (92 prosent) og signifikant lavere (p-verdi < 0,05) for Østfold (69 prosent).

Tabell 3 viser at nesten alle enhetene foretar kapillær prøvetaking og analyserer urinstrimler og/eller foretar transport av urinprøver. Glukose analyseres hyppigst (96 prosent), om lag halvparten av enhetene analyserer CRP (56 prosent) og hemoglobin (46 prosent), mens en tredjedel analyserer INR (32 prosent). Ingen av enhetene oppga at de utførte andre analyser enn de forannevnte. 
Tabell 3: Andel av enhetene som utfører ulike typer analyser

\begin{tabular}{|c|c|c|c|c|}
\hline Analyser & $\begin{array}{l}\text { Nordland } \\
\mathrm{N}=62\end{array}$ & $\begin{array}{l}\text { Sogn og Fjordane } \\
N=38\end{array}$ & $\begin{array}{l}\emptyset \text { stfold } \\
N=32\end{array}$ & $\begin{array}{l}\text { Alle tre fylkene } \\
\mathrm{N}=132\end{array}$ \\
\hline $\begin{array}{l}\text { Analyserer urinstrimler og/eller } \\
\text { transporterer urinprøver* }\end{array}$ & 94 & 97 & 100 & 96 \\
\hline Glukose (blodsukker) & 100 & 97 & 100 & 99 \\
\hline C-reaktivt protein (CRP) & 57 & 61 & 59 & 56 \\
\hline Hemoglobin & 52 & 45 & 34 & 46 \\
\hline $\begin{array}{l}\text { Protrombintid internasjonal } \\
\text { normalisert ratio (INR) }\end{array}$ & 36 & 32 & 25 & 32 \\
\hline \multicolumn{5}{|l|}{ Prosentvis fordeling. } \\
\hline \multicolumn{5}{|c|}{$\begin{array}{l}\text { *Antall ressondenter for urinstrimler avviker noe fra de andre (en mer for Nordland og en mindre for } \varnothing \text { stfold } \\
\text { sammmenliknet med det som er oppførti i tabell). }\end{array}$} \\
\hline
\end{tabular}

Alle typer ansatte utfører glukosemåling, urinstrimmeltest og transport av urinprøver, mens sykepleierne er den klart viktigste gruppen når det gjelder venøs prøvetaking. I studien vår svarer 99 prosent av enhetene at sykepleiere utfører venøs prøvetaking, mens for hjelpepleiere (helsearbeidere), vernepleiere og ufaglærte er de samme prosentandelene henholdsvis 14, 11 og 4.

Tjueåtte prosent av enhetene analyserte også om natten. Her var det en relativt stor fylkesvis variasjon: Nordland 22 prosent, Sogn og Fjordane 15 prosent og Østfold 55 prosent.

Tabell 4 viser at halvparten av enhetene i alle fylkene utførte venøs prøvetaking mer enn én gang i uken, mens andelene er langt lavere og varierer for de resterende tre analysetypene, mellom 6 og 21 prosent. Andelen som analyserte CRP, er signifikant forskjellig mellom fylkene.

\section{«Alle typer ansatte utfører glukosemåling, urinstrimmeltest og transport av urinprøver, mens sykepleierne er den klart viktigste gruppen når det gjelder venøs prøvetaking.»}

Videre følger det av tabell 4 at andelen enheter som analyserte CRP mer enn én gang uken, er høyest for Østfold. Andelen som utførte INR mer enn én gang i uken, er signifikant lavere i Sogn og Fjordane. 
Enhetene ble også spurt om hvilke typer analyser de utførte. Nesten 46 prosent av enhetene utførte minst fire av de totalt fem analysene vi spurte om: glukose, CRP, hemoglobin, INR og urinstrimmeltest. En fjerdedel utførte alle fem.

Respondentene oppga at glukose, INR og hemoglobin vanligvis ble analysert hjemme hos brukeren. CRP ble analysert både hos brukeren og i enhetens base. Urinstrimmel ble hyppigst benyttet pasientnært, dernest i enhetens base og så på legekontoret.

Tabell 4: Enheter som foretar ulike laboratorietjenester mer enn en gang ukentlig

\begin{tabular}{|c|c|c|c|c|}
\hline & $\begin{array}{l}\text { Nordland } \\
\mathrm{N}=62\end{array}$ & $\begin{array}{l}\text { Sogn og Fjordane } \\
N=38\end{array}$ & $\begin{array}{l}\emptyset_{\text {stfold }} \\
N=32\end{array}$ & $\begin{array}{l}\text { Alle tre fylkene } \\
N=132\end{array}$ \\
\hline Venøs prøvetaking & 50 & 50 & 50 & 50 \\
\hline C-reaktivt protein (CRP)* & 10 & 21 & 41 & 21 \\
\hline Hemoglobin & 7 & 3 & 9 & 6 \\
\hline $\begin{array}{l}\text { Protrombintid internasjonal } \\
\text { normalisert ratio (INR)* }\end{array}$ & 19 & 3 & 19 & 14 \\
\hline \multicolumn{5}{|l|}{ Prosentvis fordeling. } \\
\hline${ }^{*} p<0,05$ (bedømt med kjikvadrattest). & & & & \\
\hline
\end{tabular}

Tabell 5 viser at legekontorene er de viktigste samarbeidspartnerne til enhetene. Sogn og Fjordane og delvis Nordland samarbeidet i all hovedsak alene med legekontorer eller med både legekontorer og sykehjem. Østfold hadde den høyeste andelen som oppga å samarbeide med både legekontor- og legevaktenheter.

Enhetene oppga at de ofte selv valgte å rekvirere spesifikke tjenester kun basert på egne erfaringer: 44 prosent sa at de nesten alltid rekvirerer urinprøver på et slikt grunnlag, og 31 prosent at de ofte rekvirerte urinprøver for CRP. For venøs prøvetaking, hemoglobin og INR skjedde dette i langt mindre grad. Med unntak av urinprøver, der Nordland ligger noe høyere enn de andre fylkene, var det ingen signifikante fylkesvise variasjoner. 
Da vi sammenstilte våre funn for enhetene og legekontorene når det gjaldt rekvirering, viste det seg at legekontorene mente de rekvirerte en høyere andel av alle CRP-analysene enn hva som faktisk var tilfellet. Vi fant videre at 54 prosent av enhetene nesten alltid, ut fra prøvesvaret, vurderte om det var nødvendig å kontakte lege, mens kun 23 prosent av fastlegekontorene trodde at enhetene gjorde det.

117 av 135 enheter oppga at de «nesten alltid» journalførte prøveresultatene, mens 7 enheter oppga at de «gjorde dette i mer enn halvparten av tilfellene». Kun 7 prosent av fastlegekontorene rapporterte å ha inngått en skriftlig avtale med hjemmetjenesten om samarbeidstype og samarbeidsomfang.

Tabell 5: Enhetens beskrivelse av samarbeidspartnere vedrørende prøvetaking og/eller analysering av blod eller urinprøver

\begin{tabular}{|c|c|c|c|c|}
\hline Sentrale samarbeidspartnere & $\begin{array}{l}\text { Nordland } \\
\mathrm{N}=66\end{array}$ & $\begin{array}{l}\text { Sogn og Fjordane } \\
N=39\end{array}$ & $\begin{array}{l}\emptyset \text { stfold } \\
N=33\end{array}$ & $\begin{array}{l}\text { Alle tre fylkene } \\
N=138\end{array}$ \\
\hline Samarbeid med kun legekontor* & 39 & 41 & 15 & 34 \\
\hline $\begin{array}{l}\text { Samarbeid med både sykehjem } \\
\text { og legekontor }\end{array}$ & 29 & 49 & 36 & 36 \\
\hline $\begin{array}{l}\text { Samarbeid med både legekontor } \\
\text { og legevaktenhet }\end{array}$ & 23 & 10 & 33 & 22 \\
\hline Samarbeid med kun sykehjem $* *$ & 2 & 0 & 3 & 1 \\
\hline $\begin{array}{l}\text { Samarbeid med både sykehjem } \\
\text { og legevakt** }\end{array}$ & 6 & 0 & 0 & 3 \\
\hline Samarbeider ikke med noen* & 2 & 0 & 12 & 4 \\
\hline \multicolumn{5}{|l|}{ Prosentvis fordeling. } \\
\hline $\begin{array}{l}{ }_{*}^{*} p<0,05 \text { (bedømt med kjikvadrattest). } \\
{ }^{* *} p<<0,1 \text { (bedømt med kjikvadrattest). }\end{array}$ & & & & \\
\hline
\end{tabular}

Tabell 6 viser at 63 prosent av enhetene brukte egne urinstrimler, mens andelen av enheter som selv eide utstyret til måling av glukose, CRP, hemoglobin og INR, var lavere mellom 10 og 30 prosent. Videre viser tabellen at enhetene i Østfold gjennomgående eide mer utstyr enn enhetene i Nordland og Sogn og Fjordane. 
Tabell 6: Enhetene som er eiere av laboratorieutstyr

\begin{tabular}{|c|c|c|c|c|}
\hline $\begin{array}{l}\text { Prosentvis fordeling av enhetene } \\
\text { som eier eget laboratorieutstyr }\end{array}$ & $\begin{array}{l}\text { Nordland } \\
\mathrm{N}=62\end{array}$ & $\begin{array}{l}\text { Sogn og Fjordane } \\
\mathbf{N}=\mathbf{3 8}\end{array}$ & $\begin{array}{l}\emptyset \text { stfold } \\
N=32\end{array}$ & $\begin{array}{l}\text { Alle tre fylkene } \\
N=132\end{array}$ \\
\hline Glukose (blodsukker) & 34 & 29 & 25 & 30 \\
\hline C-reaktivt protein (CRP) & 19 & 21 & 34 & 24 \\
\hline Hemoglobin* & 21 & 8 & 25 & 19 \\
\hline $\begin{array}{l}\text { Protrombintid internasjonal normali- } \\
\text { sert ratio (INR) }\end{array}$ & 10 & 8 & 13 & 10 \\
\hline Urinstrimler & 60 & 58 & 72 & 63 \\
\hline \multicolumn{5}{|l|}{ Prosentvis fordeling. } \\
\hline
\end{tabular}

\section{Diskusjon}

Det er overraskende at mer enn 95 prosent av

hjemmetjenesteenhetene i Nordland, Sogn og Fjordane og

Østfold har en laboratorievirksomhet, og at en høy andel av dem utfører mange ulike typer laboratorietjenester. Alle enhetene utfører kapillær prøvetaking og analysering i brukernes hjem, mens 90 prosent av enhetene i Nordland og Sogn og Fjordane utfører venøs prøvetaking. Andelen er noe lavere i Østfold. En ulempe med å analysere et annet sted enn pasientnært er at prøvesvaret kommer senere i tid.

\section{Analyserepertoar}

Det er ikke signifikante forskjeller mellom fylkene når det gjelder analyserepertoar. Dette funnet var noe overraskende i lys av den fylkesvise variasjonen i reiseavstand.

Da vi bearbeidet resultatene, tok vi ikke hensyn til at enhetenes størrelse og reiseavstander varierte (tabell 1 og 2). I og med at brukerne i Østfold har kortest reiseavstand til alternative prøvetakingssteder, som for eksempel legevakten, hadde vi forventet et smalere analyserepertoar for dette fylket. En mulig forklaring kan være at Østfold har større enheter med flere brukere og antall årsverk, og derfor har større behov for å ha laboratorieutstyret lett tilgjengelig. 
En annen interessant observasjon var at enhetenes

analyserepertoar i noen grad sammenfalt med repertoaret til norske sykehjem (5). Andelen sykehjem og enheter som utførte urinstrimmeltest, glukose og INR, var relativt like, mens det varierte noe når det gjaldt hemoglobin og CRP: henholdsvis 79 og 95 prosent for sykehjem, 45 og 56 prosent for enhetene.

\section{Samarbeid med legekontor og legevakt}

Vi fant videre at enhetene i Østfold samarbeidet mer med legevakten og mindre med legekontorene enn de to andre fylkene. Det skyldes sannsynligvis at brukerne i Østfold har kortere reiseavstand til alternative prøvetakingssteder. Da vi sammenliknet oversiktene over analyserepertoaret og andelen utstyr som hjemmetjenesten eier, fant vi at 42 prosent av de enhetene som utfører CRP, eier instrumentene selv.

Andelen var høyest for Østfold, noe som kan ha bakgrunn i at Østfold har større enheter og derfor større behov for å ha laboratorieutstyr lett tilgjengelig. En tidligere studie fant at økt tilgjengelighet av et analyseinstrument på legekontoret medførte at den relevante analysen ble mer brukt (13). Dette funnet bekrefter altså at tilgjengeligheten av analyseutstyr alene påvirker analysehyppigheten.

\section{三 «Enhetene i Østfold samarbeidet mer med legevakten og mindre med legekontorene enn de to andre fylkene.»}

Laboratorievirksomheten i enhetene er større enn det fastlegekontorene er klar over, noe som kan skyldes at ikke alle prøvesvarene ble rapportert inn til fastlegekontorene.

Manglende svarrapportering og mangelfull journalføring kan skyldes at de manglet skriftlige avtaler som avklarte hva oppgavene til hjemmetjenestene skal være. Også BingJonsson og medarbeidere har bekreftet at det mangler dokumentering i hjemmetjenesten (9).

\section{Representativt utvalg for de tre fylkene}


Med en svarprosent på 89 og 84 fra henholdsvis

hjemmetjenesteenhetene og fastlegekontorene er det grunn til å tro at respondentene er representative for de tre utvalgte fylkene. Trolig gir våre funn også relevant informasjon om situasjonen i andre fylker. Imidlertid inkluderer studien vår ingen av Norges fem største byer, noe som betyr at vi skal være varsomme med å generalisere.

I tettbygde strøk er det for eksempel langt enklere å sende ut helsepersonell til brukerne for å foreta planlagte analyser, samtidig som brukerens reisetid og avstand til nærmeste legekontor er kortere. Eventuelle fremtidige utvidelser av analysen vår bør inkludere flere fylker og større byer. Studier kan foretas både ved å inkludere flere fylker, og ved å velge andre observasjonsenheter, for eksempel skille mellom store og små enheter.

Det er også en viss forskjell mellom enhetene når det gjelder hvem som besvarte spørreskjemaet. I Sogn og Fjordane var 82 prosent av respondentene selv enhetsledere, mens andelene var noe lavere for de andre to fylkene. Slike forskjeller kan ha påvirket funnene våre.

I studien vår har vi ikke kunnskap om antall prøver som ble analysert i den enkelte enheten og av den enkelte medarbeideren. Vi valgte ikke å spørre om slike forhold da vi vurderte det som lite sannsynlig å finne respondenter som hadde en slik oversikt. I stedet spurte vi etter antallet prøver enhetene hadde tilgjengelig, og spurte hvorvidt enhetene analyserte prøvene mer enn én gang ukentlig.

Det er sannsynlig at den enkelte medarbeideren i hjemmetjenesten sjeldnere utfører laboratoriearbeid enn medarbeidere på legekontorer, og minst like sjelden som medarbeidere i sykehjem. Derfor er det ekstra viktig med god opplæring og kvalitetssystemer.

\section{Konklusjon}

Studien vår viser at de fleste enhetene har en laboratorievirksomhet, og at denne virksomheten er relativt omfattende og mer omfattende enn hva fastlegekontorene er klar over. Dette betyr at det er mange ansatte i hjemmetjenesten som, på en eller annen måte, er involvert i laboratorievirksomhet. 
Enhetene har flere samarbeidspartnere å forholde seg til.

Derfor er det viktig at de som er involvert $\mathrm{i}$

laboratorievirksomhet, har tilstrekkelig faglig kompetanse

samtidig som de utvikler skreddersydde

kvalitetssikringssystemer for å sikre at samhandlingen mellom

fastlegekontoret, sykehjemmet og hjemmetjenesten blir

tilfredsstillende.

Sykepleiere utfører en betydelig mengde

laboratorievirksomhet. Derfor kan et viktig tiltak for å sikre faglig kompetanse være å gjøre laboratorievirksomhet til en del av grunnutdanningen deres.

Vi vil takke Marit Steinsund i Noklus for å ha bidratt i datainnsamlingen og kommet med nyttige kommentarer da vi utarbeidet artikkelen.

\section{Referanser}

1. Lov 24. juni $2011 \mathrm{nr}$. 30 om kommunale helse- og omsorgstjenester m.m. (helse- og omsorgstjenesteloven) $\S$ 3.1-3.2. Tilgjengelig fra:

https://lovdata.no/dokument/NL/lov/2011-06-24-30 (nedlastet 08.01.2018).

2. Forskrift 28. august 2012 nr. 842 om fastlegeordning i kommunene. Tilgjengelig fra: https://lovdata.no/dokument/SF/forskrift/2012-08-29-842?qForskrift om fastlegeordning i kommunene (nedlastet 08.01.2018).

3. Statistisk sentralbyrå. Omsorgstenester. 2017.

Tilgjengelig fra: https://www.ssb.no/helse/statistikker/pleie (nedlastet 13.02.2017).

4. $\quad$ St.meld. nr. 47 (2008-2009). Samhandlingsreformen. Rett behandling- på rett sted - til rett tid. Oslo: Helse- og omsorgsdepartementet; 2009.

5. Laboratorietilbud i sykehjem; Veileder for utvidelse og vurdering av laboratorietilbud i sykehjem. Tilgjengelig fra: http://www.noklus.no/Portals/2/Kurs\%20og\%20veiledning/R\%E5d\%20om\%20analyserepertoar/2014$10-$ 21\%20Laboratorietilbud\%20i\%20sykehjem\%20med\%20dato\%20\%20Veileder\%20fra\%20Noklus.pdf (nedlastet19.10.2016). 
6. Helserådet. Skal hjemmesykepleien ta blodprøver.

2013;2:6-7. Helsebiblioteket.no. Tilgjengelig

fra: http://www.helsebiblioteket.no/samfunnsmedisin-og-

folkehelse/helseradet/?index=100 (nedlastet 19.10.2016).

7. Omsorg 2020. Regjeringens plan for omsorgsfeltet

2015-2020. Oslo: Helse- og omsorgsdepartementet.

Tilgjengelig fra:

https://www.regjeringen.no/contentassets/af2a24858c8340edaf78a77e2fbe9cb7/omsorg_2020.pdf (nedlastet 15.02.2017).

8. Fauli S. Hvilken laboratorievirksomhet bør

hjemmetjenesten ha? Tidsskr Nor Legeforen 2014;134:487.

9. Bing-Jonsson PC, Hofoss D, Kirkevold M, Bjørk IT,

Foss C. Sufficient competence in community elderly care?

Results from a competence measurement of nursing staff.

BMC Nursing 2016;15:5.

10. Bing-Jonsson PC, Tønnessen S. Urinveisinfeksjon

blant eldre i hjemmesykepleien. Sykepleien. Forskning.

Tilgjengelig fra:

https://sykepleien.no/forskning/2016/11/urinveisinfeksjon-

blant-eldre-pasienter-i-hjemmesykepleien (nedlastet

08.01.2018).

11. Senter for fagutvikling og forskning, Utviklingssenter for sykehjem og hjemmetjenester i Oslo. Tilgjengelig fra: http://www.utviklingssenter.no/index.php?cat=176135 (nedlastet 17.01.2018).

12. Statistisk sentralbyrå. Folkemengde og areal, etter fylke og kommune. Tilgjengelig fra:

http://www.ssb.no/a/aarbok/tab/tab-057.html (nedlastet 17.01.2018).

13. Fauli S, Thue G. Decision making in general practice: the availability and use of a specific laboratory analysis. International Journal of Technology Assessment in Health Care. 2005;21(3):386-92. 